\title{
Wind-Solar Intelligent Controller System based on FPGA: Review Study
}

\author{
Prof. Dr. Hanan A. R. Akkar \\ Department of Electrical Engineering \\ University of Technology
}

\author{
Areeg Fadhil Hussein \\ M. Sc Student \\ Department of Electrical Engineering \\ University of Technology Ministry of Education
}

\begin{abstract}
The natural power sources are clean sustainable energy sources so it's the best solution for the pollution and the extinct of the energy sources, thus exploiting these sources in the best way was the goal of many researchers, especially these sources are in continuous change due to the movement of the earth around itself and around the sun, the terrain of the surface of earth. Some of the researchers tried to invest these sources as much as possible or even design system that combine two or more of these sources at the same time to ensure the continuity of the power source.

Many researches have been done to get the MPPT of the hybrid wind-solar system by using controlling techniques. The MPPT algorithms are divided in to two principle categories; the first category utilizes the classic methods like Perturbation and Observation (P\&O), incremental conductance and hill climbing. The second category uses the intelligent methods link artificial neural network, fuzzy logic and Practical Swarm Optimization PSO.

In this paper we present a review of various controlling techniques have been done on solar-wind hybrid system through the past few years and trying to compare their results.
\end{abstract}

Keywords: Intelligent Controller, Artificial Neural Networks (ANN), Back Propagation (BP), Particle Swarm Optimization (PSO), Hybrid Fuzzy Pre-compensated (HFP), Proportional Integrator (PI) Solar-Wind System.

\section{INTRODUCTION}

Electricity is the backbone of the present life since it's the key element in industries, medical, communication ...etc. The major sources to produce electricity are the natural gas and petroleum which both consider as nonrenewable sources and close to extinct, therefore trying to find alternative sustainable sources was the main concern for the researchers [1].

Waterwheels, wind turbines were the first known methods to generate electricity, and then the photovoltaic cells where discovered. All these sources are fluctuated to the movement of the earth as well as the terrain of the earth surface. For example, the solar-energy affected by whether it's day time or night as well as the condition of the weather and the seasons, likewise the wind energy fluctuates with seasons changes, the local terrain and the losses in the wind turbine itself.
There are many methods to overcome this nonuniform response of the solar-wind energies by using the Maximum Power Point Tracking (MPPT) algorithms which used to find the optimum position to extract the maximum power so the system reaches its idealistic performance.

The MPPT algorithms can be divided in to two categories, the first one is the classic methods like Perturbation and Observation ( $\mathrm{P} \& \mathrm{O})$, hill climbing and incremental conductance. The second one uses the intelligent methods like Artificial Neural Network (ANN), Fuzzy Logic (FL) and Practical Swarm Optimization PSO [2].

MPPT algorithms done by using Artificial Neural Networks (ANN) by training the neurons on a set of data using one of the supervised learning algorithms where the user provides the network with the desired output, back propagation BP algorithm is the most widely used algorithm and that was the main reason of NN popularity [3].

The nature inspired algorithms like PSO is the most attractive method for many researchers and especially when they used to train back propagation Neural network which would make it more convenient method to get the optimized solution for non-linear systems, that's done by updating the weights of the neurons with PSO algorithms such as Firefly algorithm [4] .

Field Programmable Gate Array (FPGA) are the best microprocessor for implementing the ANN with the for its high-speed, better performance and easy to design with.

MATLAB Simulink is the best program to simulate the solar-wind energy system and testing the algorithms to verify building the system and avoiding any modeling problems might appear in the hardware model, so MATLAB and FPGA are the best combination to design the control strategies to get the MPPT for this hybrid system.

\section{HYBRID SOLAR WIND SYSTEM MODELLING}

The hybrid system in all the subjects of the research consist of solar panel, Wind Turbine, Boost (DC to DC) converters, Field Programmable Gate Array (FPGA) controller and support Batteries as shown in Fig.1. 


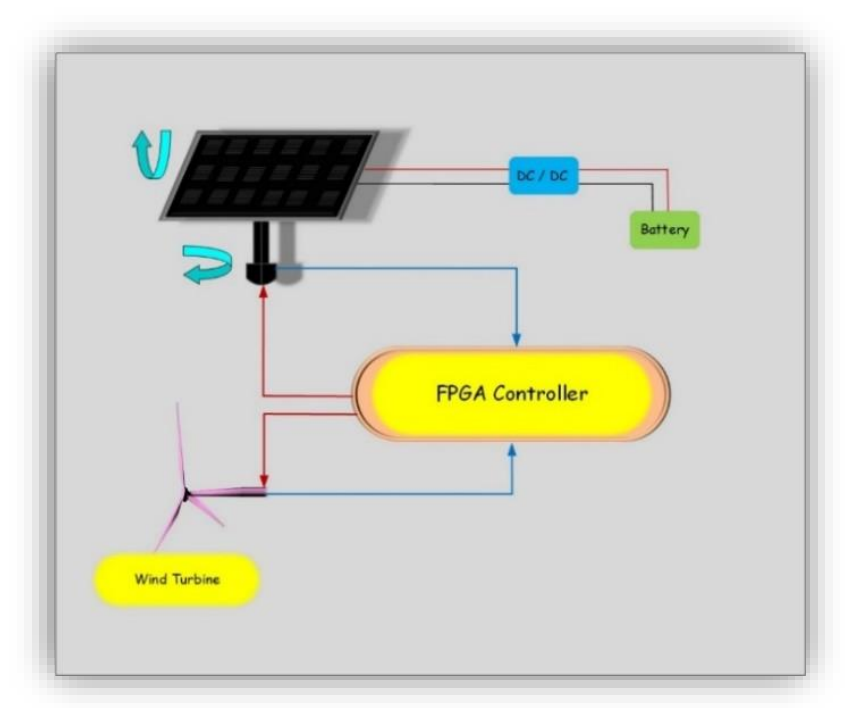

A. Solar Cells

Fig. 1- Hybrid wind solar system

Solar cells generate electricity from the sun light where the incident light on the solar panel will be converted in to electrical energy, also it known as photovoltaic cells [5].

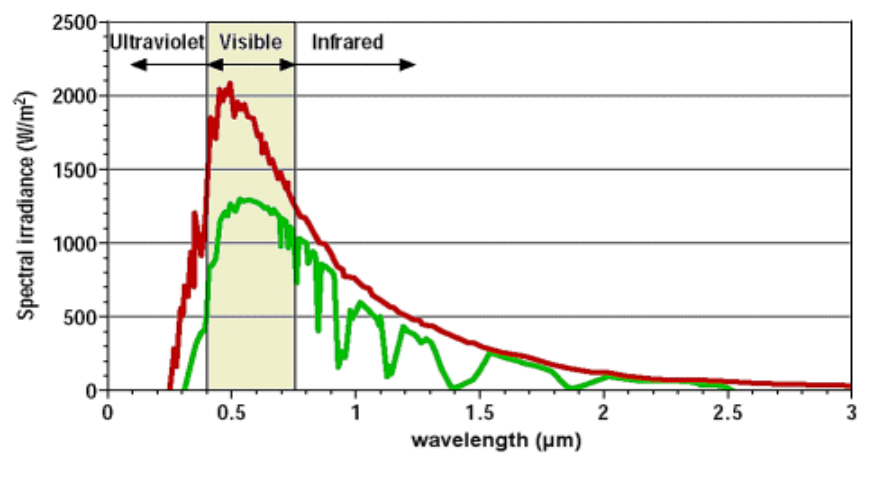

- Spectrum $A M 0$ (extraterrestrial) $\quad$ Spectrum $A M 1.5$ (terrestrial)

Fig. 2- solar spectrum

The equivalent circuit for the solar (PV) cell is shown in Fig.3 [6].

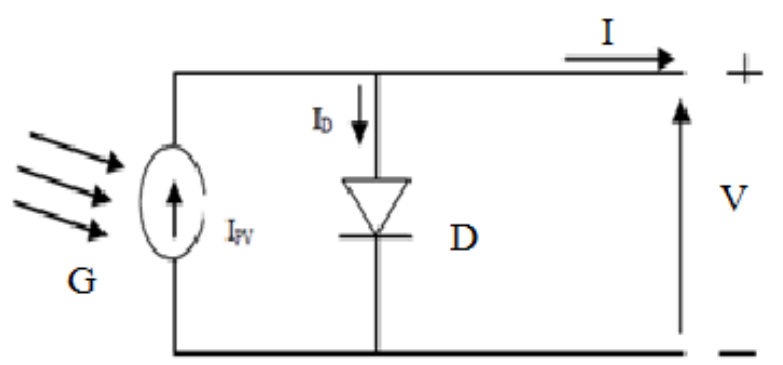

Fig.3- Ideal PV cell with single-diode
The equation for the output current is given by:

$\mathrm{I}=\mathrm{I}_{\mathrm{PV}}-\mathrm{I}_{\mathrm{D}}$

Where

$\mathrm{I}_{\mathrm{D}}=\mathrm{I}_{0}\left[\exp \left(\frac{V}{A V_{T}}\right)-1\right]$

Then equation (1) becomes:

$\mathrm{I}=\mathrm{I}_{\mathrm{PV}}-\mathrm{I}_{0}\left[\exp \left(\frac{V}{A V_{T}}\right)-1\right]$

$\mathrm{I}_{\mathrm{pV}} \mid$ is the current generated by the incidence of light.

$I_{0} \quad$ is the diode reverse bias saturation current.

$\mathrm{V}_{\mathrm{T}}=\frac{\mathrm{Ns} * \mathrm{k} * \mathrm{~T}}{\mathrm{q}}$ is the thermal voltage of a PV module.

Ns cells connected in series.

$\mathrm{q}$ is the electron charge.

$\mathrm{k}$ is the Boltzmann constant.

$\mathrm{T}$ is the temperature of the $\mathrm{p}-\mathrm{n}$ junction.

A the diode ideality factor.

\section{B. Wind Turbine}

Wind turbine system consists of Mechanical energy conversion part and Electrical energy conversion part as shown in Fig.4. [7].

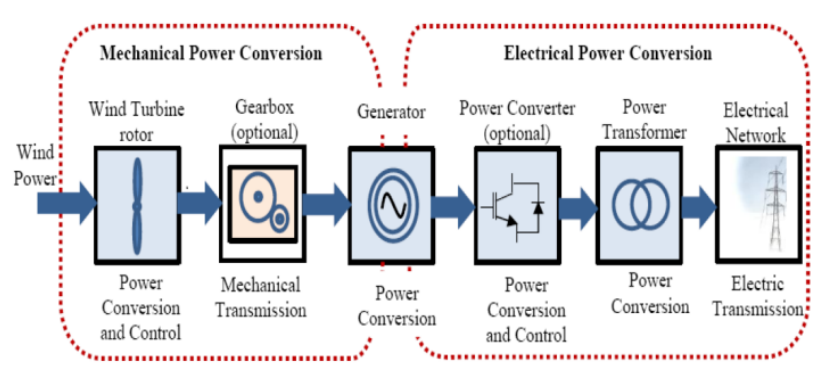

Fig.4- Wind Turbine System

The output power equation is:

$$
\mathrm{P}=\frac{1}{2} \Pi \rho \mathrm{C}_{\mathrm{P}}(\lambda, \beta) \mathrm{R}^{2} V_{v}^{3}
$$

Where:

$V_{v} \quad$ is the wind peed

$\mathrm{R}$ is the radius of the turbine

$\beta \quad$ is the pitch angle of the turbine

$\lambda \quad$ is the tip speed ratio

$C_{p} \quad$ is the power coefficient

$\rho \quad$ is the air density

the attribute curves for the power coefficient and the tip speed ratio at different pitch angles showed in Fig .4 


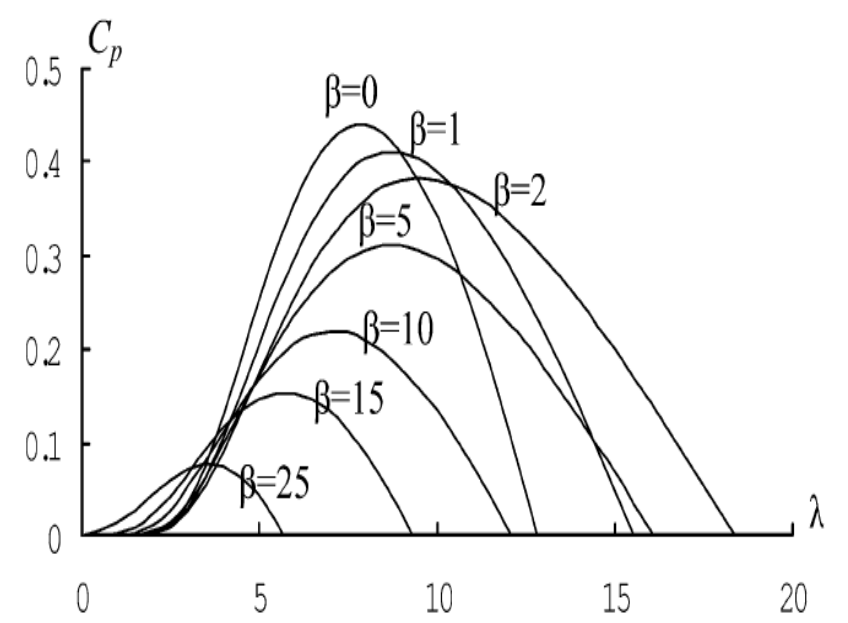

Fig.4- wind turbine attributes curves

\section{CONTROLLING TECHNIQUES FOR THE SOLAR WIND SYSTEM}

Controlling techniques are the main element of improving the system efficiency. The extracted power from the hybrid solar-wind system can be enlarged with credible cost by using convenient controlling technique in the designing process of the system.

The generated power from the solar panel and wind turbine stored in to a look up tables in the FPGA and then processed through separated pulse width modulator (PWM) controllers to each converter even though they both used Proportional Integrator but one will provide the desired voltage from the solar panel and the other provide the desired current from the wind turbine this was the system presented by M. Cirstea, et al., 2010 [8].

An intelligent controller using Artificial Neural Network (ANN) trained with Genetic Algorithm (GA) designed to extract the maximum power from the solar panel was presented by R. Ramaprabha and Mathur, 2011 [9].

At 2011 an energy controller based on FPGA that receive its input from external sensor after validating a sequence of conditions and then simulated, the proposed controller to control the rotational speed loop along with the power loop so the delivered voltage and the wind turbine pitch degree are regulated together was proposed by K. A. Toker, and N. S. Cetin [10]

An improved MPPT algorithm using an ANN and the classical P\&O algorithm to extracts the MPP from the solar array compatible with a load resistance in terms of solar radiation and ambient temperature. They found from the simulation results that the time response of the $\mathrm{P} \& \mathrm{O}$ algorithm was slower than the improved MPPT algorithm. Also, the efficiency of the classical P\&O algorithm was lower as compared to the developed ANN algorithm was presented by M. A. Younis et al., 2012 [11].
A 10kW hybrid wind-solar system with developed controller to get the maximum power from the system, an inverter is used to convert the solar and the wind output into AC to operate the load, a Battery connected to the solar or the wind turbine to support the system presented by C. Marisarla and k. Ravi Kumar, 2013 [12].

A supervisory control unit designed to evaluate MPPT for both solar panel and wind turbine in a single hybrid solar wind power generation system using the $\mathrm{P} \& \mathrm{O}$ method which provided a stable effective performance for tracking under the wind and the sun irradiation changes by D. Shen, A. Izadian, 2014 [13].

An intelligent controller using Artificial Neural Network trained with back propagation algorithm proposed for solar panel sun tracking system to produce energy from solar cell by $(44.377 \%)$ more than the solar cell without tracking system by H. A. R. Akkar and Y. M. Abid, 2015 [14].

An improved variable step-size $\mathrm{P} \& \mathrm{O}$ algorithm to implement Sinusoidal Pulse Width Modulation (SPWM) for a single-phase hybrid power filter generator for solar and wind. The algorithm then translated into Very high speed integrated circuit Hardware Description Language (VHDL) which executed on the Spartan-3 FPGA. This algorithm acts as idiomatic controller in terms of tracking speed and reduce inconsistency of the output power was presented by T. S. B. Damodhar, Dr. A. S. Kumar, 2016 [15].

A Fuzzy Logic Controller proposed to achieve the MPPT with fast time response for the solar-wind system, the controller was implemented on MATLAB and Xilinx FPGA blocks to estimate the timing response and the tracking efficiency, where the system with Xilinx System Generator (XSG) settled quickly which achieved settling time about (0.4 ms) by J. Aymen et al., 2017 [16].

Concurrent generator based solar and wind microgrid battery system developed with a prototype operate under variable conditions (different wind speed, disconnection and isolation on the solar panel) and study the system steady state as well as its dynamic performance, the results showed the effectiveness of their technique where all the load demands have been provided as presented by $\mathrm{F}$. Chishti, et al., 2018 [17].

An Artificial Neural Network controller to extract the maximum power at fixed atmospheric conditions and then optimize the system with respect to the real time qualifications so as to improve the performance of the system, ANN consist of two hidden layers one of twenty neurons and the second with single neuron all simulated by MATLAB and then implemented on XSG where the results confirmed that the system presents acceptable execution real time performance and precision as stated by O. Zarrad et al., 2019 [18].

A Hybrid (Bat-Dragonfly) Algorithm HBDFA proposed to produce the Optimum Power Flow (OPF) for the hybrid system, the Bat Algorithm (BA) had fast calculating time with faint accuracy, while the Dragonfly 
Algorithm DFA had slow calculating time with higher accuracy, thus combining the operation of both Bat and Dragonfly Algorithms showed that the precision of the controller regulation has improved with fast calculating time, that provided superior execution of the controller to regulates the parameters comparing with the existing methods as V. Gonal and G.S. Sheshadri presented in 2019 [19].

Table .1 represents the outlines of controlling techniques in the cases of study in this review with the conclusions and special findings:

\section{TABLE.1 OUTLINES OF CONTROLLING TECHNIQUES}

\begin{tabular}{|c|c|c|c|c|}
\hline Ref. & Authors & Year & $\begin{array}{l}\text { Controlling } \\
\text { technique }\end{array}$ & $\begin{array}{l}\text { Conclusion/Special } \\
\text { finding }\end{array}$ \\
\hline$[8]$ & $\begin{array}{l}\text { Marcian Cirstea, Alberto } \\
\text { Parera-Ruiz and Anglia Ruskin }\end{array}$ & 2010 & PWM & $\begin{array}{l}\text { Achieved a global } \\
\text { prototype for renewable } \\
\text { energy system } \\
\text { controlled with FPGA }\end{array}$ \\
\hline$[9]$ & $\begin{array}{l}\text { R. Ramaprabha and B. L. } \\
\text { Mathur }\end{array}$ & 2011 & ANN-GA & $\begin{array}{l}\text { The error percentage is } \\
\text { between }(0.05-4.64 \%)\end{array}$ \\
\hline$[10]$ & $\begin{array}{l}\text { Kadir A. Toker, and Numan S. } \\
\text { Cetin }\end{array}$ & 2011 & PI & $\begin{array}{l}\text { Controlling } r \\
\text { rotational speed would } \\
\text { control the output } \\
\text { power }\end{array}$ \\
\hline$[11]$ & $\begin{array}{l}\text { Mahmoud A. Younis, Tamer } \\
\text { Khatib, Mushtaq Najeeb }\end{array}$ & 2012 & $\begin{array}{l}\text { ANN and } \\
\text { classical } \\
\mathrm{P} \& \mathrm{O}\end{array}$ & $\begin{array}{l}\text { The ANN provided } \\
\text { better performance than } \\
\text { the } \mathrm{P} \& \mathrm{O}\end{array}$ \\
\hline$[12]$ & $\begin{array}{l}\text { Chaitanya Marisarla, k. Ravi } \\
\text { Kumar }\end{array}$ & 2013 & $\begin{array}{l}\text { Classical } \\
\text { MPPT }\end{array}$ & $\begin{array}{l}\text { The supporting batteries } \\
\text { with the state of charge } \\
\text { controlling technique } \\
\text { improved the } \\
\text { performance of the } \\
\text { system }\end{array}$ \\
\hline$[13]$ & Dan Shen, Afshin Izadian & 2014 & $\mathrm{P} \& \mathrm{O}$ & $\begin{array}{l}\text { stable effective } \\
\text { performance for } \\
\text { tracking under the wind } \\
\text { and the sun irradiation } \\
\text { changes }\end{array}$ \\
\hline$[14]$ & $\begin{array}{l}\text { Hanan AR Akkar and Yaser M. } \\
\text { Abid }\end{array}$ & 2015 & BP-ANN & $\begin{array}{l}\text { The output power } \\
\text { increased by } 44.377 \%\end{array}$ \\
\hline$[15]$ & $\begin{array}{l}\text { T. S. B. Damodhar, Dr. A. S. } \\
\text { Kumar }\end{array}$ & 2016 & SPWM & $\begin{array}{l}\text { The load receives a } \\
\text { constant power supply } \\
\text { from the two sources }\end{array}$ \\
\hline$[16]$ & $\begin{array}{l}\text { Jemaa Aymen, Ons Zarrad, } \\
\text { Mohamed Ali Hajjaji and } \\
\text { Mohamed Nejib Mansouri }\end{array}$ & 2017 & $\overline{\text { FLC }}$ & $\begin{array}{l}\text { The MPPT achieved in } \\
\text { a time about } 0.4 \mathrm{~ms}\end{array}$ \\
\hline [17] & $\begin{array}{lcc}\text { Farheen } & \text { Chishti, } & \text { Shadab } \\
\text { Murshid, Bhim Singh } & \end{array}$ & 2018 & HFP speed PI & $\begin{array}{l}\text { Th results showed the } \\
\text { effectiveness of the } \\
\text { control technique }\end{array}$ \\
\hline$[18]$ & $\begin{array}{l}\text { Ons Zarrad, Mohamed Ali } \\
\text { Hajjaji and Mohamed Nejib } \\
\text { Mansouri }\end{array}$ & 2019 & $\overline{A N N}$ & $\begin{array}{l}\text { The MPP achieved time } \\
4 \mathrm{~ms} \text { and tracking } \\
\text { efficiency of } 99.61 \%\end{array}$ \\
\hline [19] & $\begin{array}{l}\text { Veeresh Gonal and G.S. } \\
\text { Sheshadri }\end{array}$ & 2019 & HBDFA & $\begin{array}{l}\text { Better performance in } \\
\text { the tuming of the } \\
\text { controller parameters } \\
\text { than other methods }\end{array}$ \\
\hline
\end{tabular}

\section{CONCLUSION}

It's important to develop a localize controlling technique to find the MPP that evade the complexity of the communication system and the computation onus which appear in the single point system

Using the intelligent methods to find the perfect point that produces the maximum power for the hybrid system is the most effective way to get the best advantages of the natural sources.

From the study above we found that applying the artificial neural networks algorithms the optimum methods for finding the perfect point and keep searching for another one at all times, that will ensure the continuity of the energy generation and avoiding the system from dropping down.

\section{REFERENCES}

[1] Phebe Asantewaa Owusu1 and Samuel Asumadu-Sarkodie "A review of renewable energy sources, sustainability issues and climate change mitigation" Middle East Technical University, Northern Cyprus Campus, Kalkanli, Guzelyurt 99738, TRNC, Turkey E-mail: samuel.sarkodie@metu.edu.tr [2016].

[2] Mohammad Junaid Khan \& Lini Mathew "Comparative Study of Maximum Power Point Tracking Techniques for Hybrid Renewable Energy System” ISSN: 0020-7217 (Print) 1362-3060 (Online) Journal homepage: https://www.tandfonline.com/loi/tetn20 [2019].

[3] Mirza Cilimkovic "Neural Networks and Back Propagation Algorithm", Institute of Technology Blanchardstown, Blanchardstown Road North, Dublin 15, Ireland, mirzac@gmail.com.

[4] Sudarshan Nandy, Manoj Karmakar, Partha P. Sarkar, Achintya Das, Ajith Abraham and Diptarup Paul " Agent Based Adaptive Firefly Back-Propagation Neural Network Training Method For Dynamic Systems" University of Kalyani, Kalyani, Nadia West Bengal, India. 978-1-4673-5116-4/12/\$31.00@2012 IEEE.

[5] Brian Tull, "Photovoltaic Cells: Science and Materials", 2004 www.molchem.science.ru.nl

[6] Dr. Hanan A. R. Akkar, Nawras M. Akesh, "Artificial Intelligent Techniques for Modeling Solar Cell Based on FPGA", International Journal of Scientific \& Engineering Research (IJSER), Vol 5, Issue 1, January, 2014.

[7] Dr. Kanaan A. Jalal and Ammar F. Hameed "Performance Enhancement of Wind Energy Conversion System Based on Intelligent Techniques" thesis submitted to the department of electrical engineering in the university of technology, Baghdad, Iraq, 2017

[8] Marcian Cirstea, Alberto Parera-Ruiz and Anglia Ruskin " An FPGA Controller for a Combined Solar / Wind Power System " University, Cambridge, United Kingdom marcian.cirstea@anglia.ac.uk ,albert294@hotmail.com ,978-14244-7020-4/10/\$26.00 '2010 IEEE.

[9] R. Ramaprabha and B. L. Mathur, "Intelligent Controller based Maximum Power Point Tracking for Solar PV System", International Journal of Computer Applications, Vol. 12, No.10, January, 2011.

[10] Kadir A. Toker, and Numan S. Cetin "A FPGA Simulation and Implementation of a Wind Energy Conversion System" K. A. Toker is with Izmir University, Izmir, 35350 Turkey (email:atilla.toker@izmir.edu.tr), N. S. Cetin is with the Solar Energy Enstitute, Ege University, Izmir, 35100 (email:numan.sabit.cetin@ege.edu.tr) 978-1-61284-788$7 / 11 / \$ 26.00$ C2011 IEEE.

[11] Mahmoud A. Younis, Tamer Khatib, Mushtaq Najeeb "An Improved Maximum Power Point Tracking Controller for PV Systems using Artificial Neural Network", National University of Malaysia, ISSN 0033-2097, 2012.

[12] Chaitanya Marisarla, k. Ravi Kumar," A Hybrid Wind and Solar Energy System with Battery Energy Storage for an 
Isolated System" International Journal of Engineering and Innovative Technology, 3(3), ISSN: 2277-3754 [2013].

[13] Dan Shen, Afshin Izadian, "Modeling and Control of a Combined Wind-Solar Microgrid" Energy Systems and Power Electronics Laboratory Purdue School of Engineering and Technology, Indianapolis 46202, USA aizadian@iupui.edu .9781-4799-4032-5/14/2014 IEEE.

[14] Hanan AR Akkar and Yaser M. Abid," Design of Intelligent Controller for Solar Tracking System Based on FPGA” Eng. \& Tech. Journal, Vol.33, Part (A), No.1,2015.

[15] T. S. B. Damodhar, Dr. A. S. Kumar, "Implementation of FPGA Based Hybrid Power Generator for PV and Wind Grid Applications" Anna University, Chennai, India, Circuits and Systems, 7, 4280-4290,2016.

[16] Jemaa Aymen, Ons Zarrad, Mohamed Ali Hajjaji and Mohamed Nejib Mansouri," Hardware Implementation of a Fuzzy Logic Controller for a Hybrid Wind-Solar System in an Isolated Site", doi:10.20944/preprints 2017.09.0077.v1.

[17] Farheen Chishti, Shadab Murshid, Bhim Singh," An Intelligent Control for Synchronous Generator Based Wind-PV-Battery Microgrid System" Indian Institute of Technology, Delhi, 978-15386-9316-2/ (C2018 IEEE.

[18] Ons Zarrad, Mohamed Ali Hajjaji and Mohamed Nejib Mansouri," Hardware Implementation of Hybrid Wind-Solar Energy System for Pumping Water Based on Artificial Neural Network Controller" Studies in Informatics and Control, 28(1) 35-44, March 2019, ISSN: 1220-1766 eISSN: 1841-429X.

[19] Veeresh Gonal and G.S. Sheshadri "A hybrid bat-dragonfly algorithm for optimizing power flow control in a gridconnected wind-solar system" sagepub.com/journalspermissions DOI:10.1177/0309524X19882429 [2019].

\section{AUTHERS BIOGRAPHY}

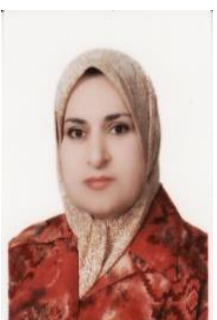

Prof. Dr. Hanan A. R. Akkar received her Bachelor's Degree from the Electrical and Electronics Engineering Department at the University of Technology in 1988. She received her Master's degree and Ph.D. degree from the Electrical and Electronics Engineering Department at the University of Technology in 1994 and 1998,

respectively. She has been Professor in the Department of Electrical Engineering at the University of Technology in the filled of ANN, FL, GA and swarm intelligent based on FPGA and electronic circuits. Currently she is Head of scientific Upgrade committee in the University of Technology.

\section{Google scholar:}

https://scholar.google.com/citations?user=WhMVTScAAA AJ\&hl=en

\section{Research gate:}

https://www.researchgate.net/profile/Hanan_Akkar

\section{Academia.edu:}

https://altadinea.academia.edu/HananAkkar

\section{LinkedIn:}

https://www.linkedin.com/me/search-appearances/

Facebook:

https://www.facebook.com/Department of Electrical Eng.

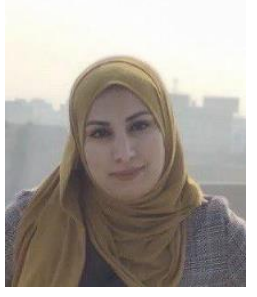

Areeg Fadhil Hussein was born in 1987 in Baghdad, Iraq. She had BSc in Electronic Engineering form Department of Electrical and Electronic Engineering at University of Technology, Baghdad, Iraq. Worked as a tutor at Directorate of Vocational Education at the Iraqi Ministry of Education. and now a M.S.c student of Electronic and Communication Engineering at the Electrical and Electronic Engineering Department at University of Technology, Baghdad, Iraq.

\section{Research gate:}

https://www.researchgate.net/profile/Areeg_Fadhil

LinkedIn:

https://www.linkedin.com/in/areag-fadhil-630084173/

Academia.edu:

https://itswtech.academia.edu/AreagA 